\title{
EU collaboration in speech and language therapy education:
}

\section{the NetQues project}

Aileen Patterson, CPLOL, Paris, France - Project Coordinator

Kristina Hansson, Lund University, Sweden

Anja Lowit, CPLOL and University of Strathclyde, Scotland UK

Jois Stansfield, Manchester Metropolitan University, England UK

Baiba Trinite, Liepaja University, Latvia

It has long been recognised that people with speech/language/communication disability require support and/or intervention. The speech and language therapy/pathology profession has grown up through well-intentioned and intuitive support offered by professionals from related fields to become a unique profession with its own scientific discipline and approach to analysing and evaluating speech, language and swallowing difficulties and offering evidence-based therapeutic interventions ${ }^{1}$. The diversity of backgrounds from which the profession has evolved has led to a rich combination of knowledge and skills being assimilated to address the complexity and range of communication development and difficulties and takes account of the interactions with cognition, social and other behaviour. Indeed this dynamic profession is continuously developing and acting upon new knowledge so that it can provide appropriate evidence based management to people of all ages with speech, language and communication needs.

The various roots from which the profession has developed are also reflected in the terminology used to describe the profession. In addition, the pre-qualifying education of the professional may also have variations in emphasis depending on whether the education programme has had origins in medicine or education or psychology/social sciences. To some extent these different emphases continue depending on the focus of the faculty/ department where the professional education programme of study is

\footnotetext{
1 The term used throughout this article is "speech and language therapy or SLT as agreed across Europe - see discussion below
} 
based. Across Europe the many different cultures, education and health systems influence perspectives of speech-language pathology and therapy education programmes. In Europe the earliest documented formal education programmes date back to the beginning of the twentieth century. Many have developed from an eclectic approach, bringing together different theoretical disciplines and perspectives from health and education to address the understanding of speech, language and communication development and breakdown. Historically in Eastern and Central European countries SLT has been mainly based in special education, drawing on the rich academic foundations established in that discipline, in particular Vygotskian theory and approaches to cognitive development and language. In other parts of Europe SLTs have been seen as health professionals with their education drawing from medical and health systems, although often also working within education systems. Comparisons of the education and scope of practice of SLTs across north, south, east and west of Europe are thus challenged by this diversity.

It is evident therefore why SLT education in Europe currently has many differing forms, and levels and of course it is taught in many different languages. Even the titles given to the profession in Europe also vary more than just in terms of translation between languages - the most common European term being "Logopaedics", English speaking countries use "Speech and language therapy/pathology" and in France/Luxembourg "orthophonie". The names of the professional in each country is listed below:

BELGIUM Logopède/logopedist

BULGARIA Logopède / Logopedist

CROATIA Logoped

CYPRUS Logopathologos / Logotherapeftis

CZECH REPUBLIC Logoped

DENMARK Talepædagog / Logopæd / Audiologopæd

ESTONIA Logopeed

FINLAND Puheterapeutti

FRANCE Orthophoniste

GERMANY Logopäd/in

GREECE Logopedikos / Logopathologos / Logotherapeftis

HUNGARY Logoped

ICELAND Talmeinafræðingur/talkennari

IRELAND Speech and Language Therapist

ITALY Logopedista

LATVIA Skolotājs logopēds /audiologopēds

LITHUANIA Logopedas

LUXEMBOURG Orthophoniste

MALTA Speech-Language Pathologist/Speech Therapist 
NETHERLANDS Logopedist

NORWAY Logoped

PORTUGAL Terapeuta da fala

ROMANIA Logoped

SLOVAKIA Logopéd

SLOVENIA Logoped/logopedinja

SPAIN Logopeda

SWEDEN Logoped

SWITZERLAND Logopédiste/ Diplomierter/e Logopäde/in

UNITED KINGDOM Speech and Language Therapist

Despite the differences in terminology and theoretical underpinning, there is a strong consensus of the role of speech-language therapists/pathologists

/logopedists/orthophonistes and what sets them apart from other health

professionals. This has been and continues to be developed further by the European

umbrella organisation, the "Comité Permanent de Liaison des Orthophonistes-

Logopèdes de l'Union Européenne" (CPLOL), which translates as Standing Liaison

Committee of Speech and Language Therapists/ Logopaedists of the European

Union. CPLOL was founded in 1988 by a group of 7 professional bodies and

maintains a bilingual French-English focus in order to allow as many nations as possible to participate. Its membership has steadily grown as the European Union (EU) has enlarged, with new professional bodies which meet the criteria to represent the profession in their country, being admitted into its membership. As of June 2014 CPLOL is now composed of 35 professional organisations of speech and language therapists / logopedists in 32 countries.

Speech and language therapy (SLT) is now globally recognised as an autonomous profession with legal regulation at national level in many countries. SLT education across Europe is diverse, vibrant and as stated above constantly evolving. The profession, however, finds itself at differing stages of development in different countries. Through working together, however, there are drives to become much more similar though not necessarily identical across national borders. The motto of the European Union "United in Diversity" certainly rings true for our profession. As the EU has developed and increased in its membership, so also has the accompanying legislation to encourage cross border mobility and recognition of qualifications across member states. This has led to a need to be able to assess and analyses education programs within the EU and beyond. 
With the many different curricular structures, levels of initial education and terminology in SLT education programmes across the countries, it is thus no mean challenge to make comparisons. One sensible way to do this has been to look at the expectations of competences of the qualified professional SLT in the European work force. The EU has developed methods of comparing educational provision across Europe, using a methodology applicable across different professions. This need to provide methods for comparing across countries has been highlighted in the Bologna declaration (EHEA, 1999) and its sequelae in creation of the European Higher Education Area (EHEA), including the establishment of the European Qualifications Framework (EQF) for lifelong learning (2005).

It was evident to those professionals committed to SLT education that in order to capitalise on the added value of such diversity of expertise and knowledge that better understanding of colleagues and professional education in other countries was paramount to unity of the profession across the countries of the EU. The SLT NetQues project therefore set out to establish agreements on areas of commonality in SLT education. It was also designed to look at its differences in a structured way using accepted scientific methodologies. Sharing of best practices could thus be facilitated and all could benefit. Education programs could also be enhanced from the greater pool of knowledge.

All EU countries had to be enlisted to sign up to share information and work together. A key target was initially to delineate the agreed common core competences which are both essential and desirable for a newly qualified SLT to be able to practise the profession safely and effectively. In order to follow robust research procedures, the NetQues project embraced the European Tuning principles which had been tried and tested in other professions. This rigorous process allows the seeking out of points of reference, convergence and common understanding, to serve as "a platform for developing reference points at subject area level" 2 These actions made a starting point for an ambitious project aiming to meet the aspirations of the SLT profession and those of the EU, to allow easier comparisons and understanding of similarities

\footnotetext{
2 González, J. and Wagenaar, R. (2003). Tuning educational structures in Europe. Bilbao: University of Deusto. Retrieved 15-06-2013 http://www.relint.deusto.es/TUNINGProject/documentos/Tuning phase1/ introduction page 1
} 
and differences in academic programmes and of the qualified SLT professionals' profiles across 32 countries.

The project was thus called Network for Tuning Standards and Quality of Education Programs in Speech and Language Therapy/Logopaedics across Europe (NetQues): a multilateral academic and professional network.

The three-year long NetQues project (2010-2013) was initiated and coordinated by CPLOL. This in itself was a major undertaking for an organisation dependent upon individuals, appointed by their professional associations as experts within the profession but nevertheless giving of their time and expertise voluntarily to travel to meetings across Europe and for most to communicate in a language which was not necessarily their own first language. In order to get a good mix of both SLT academics and full time clinicians the project brought together representatives form University/Higher education and professional associations from across EU member countries, in a multilateral academic and professional network. Sixty five partnership agreements were set up with the Universities and professional associations across 27 EU member country states, plus Liechtenstein, Norway and the EU-candidate countries of Iceland and Turkey. Partners were predominantly academic institutions but also included some professional associations.

The NetQues project was undertaken with support from the European Union. The project has been co-funded by the European Commission's ERASMUS Lifelong Learning Programme through the Education Audiovisual \& Culture Executive Agency. The opening meeting of partners' representatives, all of whom were engaged in setting and maintaining high standards in SLT education, was held in Paris in October 2010, to agree the goals and methods. From the start, despite the many different backgrounds and countries from which the partners came, there was a strong sense of commitment to work together and overcome differences for the benefit of the profession. At the outset, recognising the need to communicate easily through the diversity, partners agreed that English should be the main language and thus the term used throughout the project to describe the profession should be the term 'speech and language therapist', and SLT to be the acronym, although fully acknowledging the professional is also commonly known by the terms 'logopaedist' and 'orthophoniste'. 
One of the first main agreed goals was to establish working terminology to avoid any undue misunderstandings and for meaningful comparisons of data, which was an essential feature of the research. The publication of a glossary for use alongside data gathering such as surveys was therefore integral to the research.

The key aims of the project were:

- $\quad$ to define the academic and professional profiles of SLT across Europe

- $\quad$ to describe the objectives of the pre-qualifying educational programmes and the learning outcomes that must be met by prospective SLTs studying in those programmes

- $\quad$ to identify the generic and subject-specific competences which SLT students should achieve and

- $\quad$ to share best practice in teaching, learning and assessment of SLT students across universities and higher education institutions in the EU.

\section{Methods}

Partners were allocated to one of six work package (WP) teams, reflecting a range of expertise and geographical spread within each team. Targets which aligned with the Tuning process lines were then assigned to each of the WP teams.

WP1 (Management) comprised the steering group (experts from partners representing a range of EU countries, academic and professional contexts) and was responsible for oversight and financial management of the project; also for organisation of all meetings by Skype and face to face, including annual meetings of all countries in Berlin, 2011, Riga, 2012 and all partners and invited key decision makers in Ghent in 2013.

WP2 (Tuning 1) was responsible for designing and circulating surveys on generic and subject specific competences.WP3 (Tuning 2) in cooperation with WP2 had overall responsibility for analysing the outcomes of the data collected with the surveys and in producing the resulting benchmarks.WP4 (Quality Assurance) was responsible throughout for ensuring quality assurance of the project, its management and the integrity of its processesWP5 (Dissemination) focused on ensuring that information about the project, its goals and promotion of best practice in EU SLT education were 
made as widely available to as many key stakeholders and interested parties as possible.WP6 (Exploitation) focused on making the best use of the resulting products, working closely with WP5 on gathering and disseminating examples of best practice as well as looking to ways of making sure that positive outcomes would be used, sustained and continue to be developed and influence change where necessary.

Each WP team took responsibility for one or more elements of the work, shared across the partners. An ethnographic research approach was adopted using the broad range of expert participants as key informants. In order to provide as complete an overview as possible of this diversity and map the current state of the art of SLT education, surveys explored the diversity of the qualifications in SLT. Results gave profiling information.

In the first survey the respondents were asked to judge 98 competences, generated by panels of experts and refined by several iterations across panels. These included both generic and subject specific competences and respondents were asked to rate these as essential, desirable, or not essential to be able to begin to practise as a newly qualified SLT. The 98 competences are all within the SLT scope of practice but the survey was intended to identify those necessary for a new graduate to be ready to practise. In order to allow all respondents to make judgements in their own first language the survey questionnaire was translated and back translated into 24 different European languages and sent out to three groups of respondents in each participating country: academic staff of SLT programs; recent graduates from SLT programs; and employers of SLTs. The translations were made by qualified SLTs who were proficient in both English and their own language and back-translated by others. A Glossary of terms was created in each language to ensure as accurate and unambiguous translation as possible.

In the second survey the structure of SLT education across Europe was studied using a 71 item survey distributed to all the departments involved in the NetQues project and also to non-participating SLT departments across the EU. Information was requested concerning curriculum structure and design; level and content of programs; number of years of study; approaches to learning, teaching and assessment; credit system and number of credits awarded; quality assurance processes; and frameworks influencing program delivery. 
In the third survey national data and statistics were gathered in collaboration with CPLOL's education commission. This survey contained 30 questions regarding national data on numbers and types of SLT programs, numbers of students, graduates, numbers in employment, population data and details of state regulation. This survey was distributed through national professional associations and colleagues.

\section{Results: Communication unites our diversity}

\section{Results from the survey 1 :}

\section{Benchmarks for SLT education: European standards to practise SLT}

A total of 4383 responses were received for the first survey. Of these $2863(65 \%)$ were fully completed and used for analysis. Academics, graduates and employers showed a high degree of agreement on what is essential in order to be able to start to practise as a newly qualified SLT, notwithstanding differences in emphasis.

Subject specific competences most often cited as essential were related to six of the eight areas identified, namely: scope of practice; assessment and identification of communication disorders and swallowing difficulties; planning and implementation of intervention; planning, maintaining and evaluating services; prevention; and professional development, continuing education and specific ethical responsibilities. All the items of generic competences in the area of interpersonal and intrapersonal competences included in the survey were among those most often cited as essential by all respondents. Intrapersonal competences included honesty, self-awareness and reflectiveness. The interpersonal skills most often cited were the ability to provide accurate feedback in a comprehensible and sensitive manner and empathy. Systemic competences and instrumental competences were in general considered as less important.

This set of competences resulting from the NetQues project, are those deemed by the EU SLT profession to be essential for a newly qualified SLT and reported in NetQues (2013). This document can be regarded as the EU-wide agreed common standards which every SLT must meet in order to practise the profession. These also provide benchmarks for SLT initial education and should be addressed in all European SLT education programmes. The benchmarks are reproduced at the end 
of this article. They should be regarded in their entirety as the core requirements for fitness to practise as an SLT.

All higher education institutions offering SLT courses, and those considering setting up new SLT courses, should have regard to these competencies. They will also offer new graduates of SLT - and perhaps established SLTs, too - a checklist against which they can audit their own skills and achievements.

\section{Results from the surveys 2 and 3: \\ Profile of SLT Education across Europe}

A total of 93 responses were received to the departmental survey, survey number 2 , and they provided specific data on curriculae at programme level. A total of 29 responses were received to survey number 3 , on national data. These results provide together a brief description of the nature and type of SLT education in each participating European country with education programmes and also included are Switzerland (Liechtenstein has no programme, neither has Luxembourg) and Turkey. Together the results of surveys 2 and 3 provide a snapshot of the state of the art of education for SLTs across Europe in 2013 and provide tools for further enquiry or comparisons. These snapshots can be seen in the NetQues (2013) project report on the web page: www.netques.eu/?page id=1051

Main results from surveys 2 and 3 indicate that SLT programmes in Europe are typically within universities, mainly state funded and predominantly organised in faculties with other health related programmes. Germany is an exception, with over 100 college based sub-degree, an issue causing considerable disquiet for that country's senior SLT professionals. A bachelor's degree (with a variety of named outcomes) is the most common route to professional qualification. Masters degrees are necessary in some countries and for a small number of institutions a graduate may practise after completing a $\mathrm{PhD}$ or a clinical doctorate, although there are also other routes permitting entry to the profession in these countries.

60 European Credits are normally awarded per academic year. The European Credit Transfer and Accumulation System (ECTS) is a system for credit accumulation and transfer across programmes of study. For example one week of study equates to 40 hours and is awarded 1.5 ECTS. The system is designed to quantify and specifying 
learning outcomes in relation to student workload needed to achieve the desired result. This can enable comparisons and allow students to exchange across courses and countries. (See http://ec.europa.eu/education/tools/docs/ects-guide en.pdf)

The evidence from the surveys however suggests that despite this countries count credits in different ways. This is especially true of practical clinical work which may be fully or partly integrated into the academic studies or treated separately. When students are admitted on to SLT education programmes, some may take account of earlier gained ECTS especially if conversion type programmes. This makes accounting of totals required prior to the qualification to practise somewhat complex. Almost all established programmes (96\%) in the departments surveyed are regulated by the state or the government. Programmes almost always have to be approved or validated by their host institution (99\%) and need to be reviewed periodically. In addition to academic prerequisites, other entrance prerequisites are applied in almost all cases, including interviews, oral examinations, speech and voice tests, and language competence tests. There are frequently limits applied to the number of students allowed onto SLT programmes. The availability of supervised clinical placement is frequently cited as a limiting factor.

\section{Conclusions}

The main tangible outcome of the NetQues project was the identification of EU-level benchmarks for SLT education and for the clinical competencies of newly qualified SLTs which should be applied across the EU (Annexed below). These have been translated into all the languages of the partners - and also beyond Europe. Perhaps, however, the best potentially enduring outcome could be considered the creation of a Network for ongoing collaborations and spin off research /projects/sharing of best practice between academic institutions and professional bodies both within and across countries. In some cases such links within countries already existed and were strong but in others the project was the catalyst to encourage closer collaborations in ensuring education of SLT professionals is research/ evidence based and grounded in making sure the education targets what is required of the professional to meet the needs of its clients in a constantly changing environment. All partners enjoyed the benefit of meeting with and sharing ideas across a very 
diverse range of SLT academics and clinicians from countries east, west, north and south within Europe. Such positive outcomes have the potential to enhance student education, promote cross border collaboration in education and research and ultimately to improve the SLT service.

The project report (NetQues, 2013) with full details of the results, an executive summary and examples of good practice are available for download on the web site at www.netques.eu Summary Profile of Key Features of Speech and Language Therapy Education by EU Country are to be found as ANNEX I I of the project report

The key Benchmarks / Competences for a newly qualified SLT at the point of entry to the profession are set out in the Annex below.

\section{References}

European Higher Education Area (1999) The Bologna declaration of 19 June 1999. Joint declaration of the European Ministers of Education http://www.bolognabergen2005.no/Docs/00-Main doc/990719BOLOGNA DECLARATION.PDF retrieved 9.10 .13

European Qualifications Framework for lifelong learning (2005) http://ec.europa.eu/education/policies/educ/eqf/com 20060479 en.pdf retrieved 7.10 .13

NetQues (2013) NetQues Project report: Speech and Language Therapy Education in Europe: United in Diversity. http://www.netques.eu/?page id=1051 retrieved 12.1.14

European Commission ECTS Users' Guide (2009) Luxembourg: Office for Official Publications of the European Communities http://ec.europa.eu/education/tools/docs/ects-guide en.pdf retrieved 7.03.15

NB This publication reflects the views only of the authors, and the European Commission cannot be held responsible for any use which may be made of the information contained therein

\section{ANNEX I Benchmarks for Speech and Language Therapy Education in Europe.}


Key subject specific and generic competencies which form common standards for European SLT initial education (NetQues, 2013)

\section{SUBJECT SPECIFIC COMPETENCES FOR THE NEWLY QUALIFIED SLT}

\begin{tabular}{|c|c|}
\hline & The newly qualified SLT must be able to: \\
\hline \multirow[t]{2}{*}{ Scope of practice } & assess, diagnose and intervene in speech and language disorders \\
\hline & $\begin{array}{l}\text { assess, diagnose and intervene in eating, drinking and swallowing } \\
\text { disorders }\end{array}$ \\
\hline \multirow{20}{*}{$\begin{array}{l}\text { Assessment and } \\
\text { identification of } \\
\text { communication needs } \\
\text { and swallowing problems } \\
\text { Planning and } \\
\text { implementation of } \\
\text { intervention }\end{array}$} & $\begin{array}{l}\text { establish rapport and facilitate participation in the assessment and } \\
\text { differential diagnosis process }\end{array}$ \\
\hline & $\begin{array}{l}\text { identify the influence of different situations, environments or contexts } \\
\text { on clients problems }\end{array}$ \\
\hline & $\begin{array}{l}\text { analyze, and interpret assessment results accurately and integrate } \\
\text { information from case history and other relevant sources into findings }\end{array}$ \\
\hline & $\begin{array}{l}\text { provide appropriate feedback on interpretation of assessment results } \\
\text { to the client and significant others, in a way they can understand easily }\end{array}$ \\
\hline & $\begin{array}{l}\text { produce oral and written reports of assessment results, including } \\
\text { analysis and interpretation of assessment information }\end{array}$ \\
\hline & $\begin{array}{l}\text { identify gaps in information needed to understand the client's } \\
\text { disorders, and seeks information to fill those gaps }\end{array}$ \\
\hline & $\begin{array}{l}\text { recognize the effect of the disorders on the psychosocial wellbeing, } \\
\text { social and medical status of the client and significant others }\end{array}$ \\
\hline & $\begin{array}{l}\text { when necessary, refer client to other professionals in a timely } \\
\text { appropriate manner }\end{array}$ \\
\hline & $\begin{array}{l}\text { integrate assessment results with other relevant information to set } \\
\text { goals }\end{array}$ \\
\hline & $\begin{array}{l}\text { understand the rationales and principles that underlie specific therapy } \\
\text { methods }\end{array}$ \\
\hline & $\begin{array}{l}\text { discuss long-term outcomes and decide, in consultation with the client, } \\
\text { whether speech and language therapy is appropriate or required by } \\
\text { including key people in these discussions }\end{array}$ \\
\hline & $\begin{array}{l}\text { select and plan appropriate and effective therapy interventions } \\
\text { involving key people in the client's environment }\end{array}$ \\
\hline & $\begin{array}{l}\text { understand the roles of other members of the inter- / transdisciplinary } \\
\text { team and produce intervention plans in consultation with them }\end{array}$ \\
\hline & $\begin{array}{l}\text { implement appropriate therapy techniques using the necessary } \\
\text { materials and instrumental equipment }\end{array}$ \\
\hline & $\begin{array}{l}\text { make reasoned decisions to initiate, continue, modify or cease the use } \\
\text { of chosen techniques, treatments or procedures, and record the } \\
\text { decisions and reasoning appropriately }\end{array}$ \\
\hline & $\begin{array}{l}\text { document response to intervention and any changes in intervention } \\
\text { plan }\end{array}$ \\
\hline & $\begin{array}{l}\text { keep legible and accurate contemporaneous records in accordance } \\
\text { with professional and legal requirements and use only accepted } \\
\text { terminology }\end{array}$ \\
\hline & $\begin{array}{l}\text { collect information, including qualitative and quantitative data, to } \\
\text { evaluate the effectiveness of therapy }\end{array}$ \\
\hline & $\begin{array}{l}\text { prepare a client for discharge from therapy appropriately, agreeing a } \\
\text { point of closure with the client and significant others, and follows } \\
\text { relevant agency discharge procedures }\end{array}$ \\
\hline & $\begin{array}{l}\text { understand the concepts of efficacy and efficiency in relation to SLT } \\
\text { intervention }\end{array}$ \\
\hline Prevention & $\begin{array}{l}\text { prevent communication and swallowing disorders from occurring or } \\
\text { developing, including early intervention in disorders }\end{array}$ \\
\hline
\end{tabular}




\begin{tabular}{|l|l|}
\hline $\begin{array}{l}\text { Professional } \\
\text { development, continuing } \\
\text { education and specific } \\
\text { ethical responsibilities }\end{array}$ & $\begin{array}{l}\text { understand the professional roles and boundaries of a speech and } \\
\text { language therapist }\end{array}$ \\
\cline { 2 - 2 } & $\begin{array}{l}\text { observe the code of ethics of the national professional body and / or } \\
\text { as prescribed by the employer, and / or the national / state government }\end{array}$ \\
\cline { 2 - 2 } & $\begin{array}{l}\text { develop personal growth as a speech and language therapist through } \\
\text { insight into, and further development of, a range of interpersonal and } \\
\text { communication skills }\end{array}$ \\
\hline
\end{tabular}

GENERIC COMPETENCES FOR THE NEWLY QUALIFIED SLT

\begin{tabular}{|c|c|}
\hline & The newly qualified SLT must be able to: \\
\hline \multirow{9}{*}{$\begin{array}{l}\text { Interpersonal and } \\
\text { intrapersonal } \\
\text { competences }\end{array}$} & demonstrate a behavior which is honest, sincere and reliable \\
\hline & demonstrate empathy with clients and colleagues \\
\hline & extract information from informants efficiently and sympathetically \\
\hline & provide accurate feedback in a comprehensible and sensitive manner \\
\hline & $\begin{array}{l}\text { demonstrate advanced social skills such as assertiveness, } \\
\text { cooperation, negotiation }\end{array}$ \\
\hline & appreciate diversity and multiculturalism \\
\hline & show positive attitude and pro activeness \\
\hline & be self-critical and reflect on their own performances \\
\hline & $\begin{array}{l}\text { demonstrate resilience in coping with the demand of the profession in } \\
\text { a way which enables him/her to maintain self-esteem and manage } \\
\text { stress }\end{array}$ \\
\hline \multirow[t]{5}{*}{ Systemic competences } & $\begin{array}{l}\text { take responsibility for developing his/her own knowledge and skills } \\
\text { throughout his/her lifespan }\end{array}$ \\
\hline & work independently and autonomously \\
\hline & adapt his/her own behavior and approach to fit new situations \\
\hline & formulate creative and original solutions for novel situations \\
\hline & $\begin{array}{l}\text { conduct a search of the scientific literature to find the most relevant } \\
\text { information to answer a question }\end{array}$ \\
\hline \multirow[t]{11}{*}{$\begin{array}{l}\text { Instrumental } \\
\text { competences }\end{array}$} & $\begin{array}{l}\text { use appropriate, effective skills and materials in written, oral and visual } \\
\text { communication of information and instruction }\end{array}$ \\
\hline & $\begin{array}{l}\text { gather data using various methods including literature review, } \\
\text { interviewing, questionnaire and observation }\end{array}$ \\
\hline & $\begin{array}{l}\text { identify the important factor in a problem and suggest possible } \\
\text { solutions }\end{array}$ \\
\hline & $\begin{array}{l}\text { express the preferred solution/decision in a comprehensible way and } \\
\text { outline the concrete actions required }\end{array}$ \\
\hline & identify the risks or pitfalls associated with each possible solution \\
\hline & $\begin{array}{l}\text { use this knowledge to select the most appropriate solution for the } \\
\text { particular circumstances }\end{array}$ \\
\hline & $\begin{array}{l}\text { analyze information to draw appropriate conclusions and recognize the } \\
\text { implications of these conclusions }\end{array}$ \\
\hline & $\begin{array}{l}\text { synthesize information from diverse sources to select an appropriate } \\
\text { course of action or to answer a question }\end{array}$ \\
\hline & $\begin{array}{l}\text { apply legal and ethical principles in managing information and protect } \\
\text { integrity, reliability and authenticity of records }\end{array}$ \\
\hline & $\begin{array}{l}\text { divide tasks into concrete steps and set time schedules with realistic } \\
\text { aims, taking into account all other demands }\end{array}$ \\
\hline & meet goals or deliver products of work on schedule \\
\hline
\end{tabular}

